\title{
DOA DAN HARAPAN AKAN ALLAH YANG MEMBEBASKAN SEBUAH TAFSIRAN POST-KOLONIAL DANIEL 9:1-27
}

\author{
Nefry Christoffel Benyamin \\ Sekolah Tinggi Theologia Abdiel \\ nefrychris@gmail.com
}

\begin{abstract}
This writing tries to interprete one of the chapters in the Book of Daniel, especially Daniel 9:1-17 by using post-colonial perspective. The perspective invites the readers to realize that they inherited the values from the colonialization time and therefore they need to re-think critically the interpretation of biblical texts which are fulfilled by the values of colonialism. Daniel 9:1-27 talks about God's hope that makes His people to experience God's freedom. Based on the texts above, the writer makes reflections about its meaning and tries to apply it in the context of the Church in the present situation.
\end{abstract}

Keywords: Post-colonial, Interpretation, prayer, liberation, Colonialism

\section{Pendahuluan}

Penafsiran teks-teks Alkitab pada umumnya berangkat dari penggalian konteks di mana teks itu ditulis. Kemudian makna dari isi teks tersebut juga dicari dan berusaha dihubungkan dengan konteks masa kini (relevansinya). Dalam menghubungkan dengan konteks masa kini, seringkali penafsiran kita dipengaruhi oleh perspektif-perspektif kolonial yang tanpa disadari menguasai pola berpikir kita. Tulisan ini akan secara khusus membahas dan menafsirkan Daniel pasal 9, sekaligus melihat bagaimana itu diinterpretasi pada masa kini dalam konteks Indonesia dengan memperhatikan perspektif post-kolonial. Memperhatikan perspektif post-kolonial artinya adanya kesadaran bahwa pembaca mewarisi nilai-nilai dari zaman penjajahan dan berusaha menghadapinya secara kritis. ${ }^{1}$

\section{Pengantar Singkat Kitab Daniel}

Pada bagian ini, akan dijelaskan terlebih dahulu introduksi singkat mengenai kitab Daniel dan konteks penulisannya.

1 Bnd. R. S. Sugirtharajah, Postcolonial Criticism and Biblical Interpretation, (Oxford: Oxford Universiy Press, 2002), h. II-123; dan R. S. Sugirtharajah, The Bible and Empire: Postcolonial Explorations, (Cambridge: Cambridge University Press, 2005), 2-3. 
Kitab Daniel terdiri dari dua belas pasal dan dapat dibagi menjadi dua bagian besar yaitu Daniel A, pasal 1-6 dan Daniel B, pasal 7-12. ${ }^{2}$ Bagian pertama kitab Daniel (pasal 16) menceritakan tentang kisah orang Yahudi buangan, Daniel dan ketiga temannya di istana Nebukadnezar dan raja-raja penerusnya; sedangkan bagian kedua (pasal 7-12) menceritakan tentang penglihatan-penglihatan atau visi-visi yang dilihat oleh Daniel dan interpretasi/ penjelasan penglihatan-penglihatan itu oleh malaikat kepada Daniel. ${ }^{3}$ Gaya bercerita antara Daniel A dan Daniel B juga berbeda, di mana dalam Daniel A digunakan bentuk orang ketiga sedangkan dalam Daniel B digunakan bentuk orang pertama. ${ }^{4}$ Dalam kitab Daniel ini, juga dapat ditemukan penggunaan dua bahasa, yaitu bahasa Ibrani dan bahasa Aram. Bahasa Ibrani dipakai dalam Daniel pasal 1-2:4a dan dilanjutkan pada pasal 8 sampai pasal 12; sedangkan bahasa Aram dipakai dalam pasal 2:4b sampai pasal 7:28. ${ }^{5}$

Biasanya kitab Daniel digolongkan ke dalam sastra apokaliptik oleh karena adanya unsur-unsur apokaliptik dalam kitab ini, seperti adanya penglihatan-penglihatan mengenai akhir sejarah ataupun akhir dari suatu zaman tertentu. ${ }^{6}$ Tetapi dalam penempatannya pada kanon Alkitab, yaitu kanon Ibrani dan kanon Septuaginta (Yunani), berbeda. Dalam kanon Ibrani, kitab Daniel ditempatkan pada bagian "tulisan-tulisan" dan dalam kanon Septuaginta (Yunani) ditempatkan pada bagian "kenabian". 7 Mungkin ini disebabkan karena kanon Ibrani lebih menekankan pada bagian pertama dari kitab Daniel sehingga dianggap sebagai kitab sastra dan ditempatkan pada kategori tersebut; sedangkan dalam kanon Septuaginta (Yunani), mungkin yang lebih ditekankan adalah bagian kedua kitab ini, yaitu pada penglihatan yang diterima oleh Daniel sehingga dimasukkan ke dalam bagian kenabian (selain tentunya tradisi-tradisi yang melihat Daniel sebagai seorang nabi, seperti Fragmen Qumran, sumber-sumber Yudaisme awal dan perkataan Yesus dalam Mat. 24:15). ${ }^{8}$ Dalam kanon Septuaginta (Yunani), kitab Daniel jauh lebih panjang jika dibandingkan dengan kanon Ibrani. Dalam kanon Septuaginta (Yunani) ada tambahan-

\footnotetext{
${ }^{2}$ Lih. Andre Lacocque, The Book of Daniel (London: SPCK, 1979), xvii.

${ }^{3}$ Norman W. Porteous, Daniel, The Old Testament Library (London: SCM Press, 1965), 13.

${ }_{5}^{4}$ Lacocque, The Book, xvii, 14.

5 Ibid, h. 13-14. Lebih lanjut mengenai masalah penggunaan dua bahasa dalam kitab Daniel ini dapat dilihat dalam John J. Collins, Daniel, Hermeneia Series (Minneapolis: Fortress Press, 1993), 12-24.

${ }^{6}$ E. Gerrit Singgih, "Dari "Godzilla" Ke "Bandot”: Fungsi Penglihatan Mengenai Binatang-binatang Di Daniel 7-8 Dalam Bagian Kedua Kitab Daniel”, dalam Y. M. Setyo Marsunu (ed.), Apokaliptik (Jakarta: LBI, 2007), 20-21. Lih. juga S. M. Siahaan \& Robert M. Paterson, Tafsiran Alkitab: Kitab Daniel: Latar Belakang, Tafsiran dan Pesan (Jakarta: BPK Gunung Mulia, 1994), 17-19; Lacocque, The Book, 4-7.

${ }^{7}$ Lacocque, The Book, 12.

${ }^{8}$ C. L. Seow, Daniel (Louisville: Westminster Bible Companion, Westminster John Knox Press, 2003), 2-3. Bnd. Siahaan, Tafsiran Alkitab, 11; Porteous, Daniel, 13.
} 
tambahan, seperti "Doa Azariah", "Nyanyian Tiga Orang Muda”, "Susanna”, "Bel” dan "Naga", yang tidak dijumpai dalam kanon Ibrani. ${ }^{9}$

Mengenai penulis kitab Daniel, tidak ada sumber atau informasi yang pasti untuk menentukan siapa penulis kitab ini. Tetapi berdasarkan isi dan pesan dari kitab Daniel ini, dapat diduga bahwa mungkin penulis kitab Daniel adalah dari kalangan maskilim atau orang-orang berhikmat. ${ }^{10}$ Berkaitan dengan waktu penulisan kitab Daniel, umumnya kalangan konservatif beranggapan bahwa kitab ini ditulis pada abad ke-6 SZB (Sebelum Zaman Bersama). ${ }^{11}$ Asumsi mereka mungkin didasarkan pada pandangan tradisional bahwa Daniel sendiri yang menulis kitab ini pada masa pembuangan atau bahwa kronologi waktu yang ditemukan dalam kitab Daniel yaitu sekitar masa pembuangan di Babel (Mis: Dan. 1:1; 2:1; dst.). ${ }^{12}$ Tetapi pandangan ini memiliki banyak sekali kelemahan. Salah satu kelemahan itu misalnya dapat dilihat pada ketidakakuratan pada fakta sejarah yang dipakai penulis berkaitan dengan masa pembuangan, sebagai contoh Belsyazar bukanlah anak dari Nebukadnezar melainkan anak dari Nabonidus. ${ }^{13}$ Sehingga dengan demikian, bagaimana mungkin seorang yang hidup dan menulis pada masa pembuangan bisa salah dalam menyampaikan informasi-informasi sejarah pada zamannya.

Yang lebih mungkin adalah bahwa penulis kitab ini hidup di zaman yang jauh dari masa pembuangan sehingga banyak informasi sejarah yang keliru muncul dalam tulisannya. Oleh karena itu lebih dapat diterima dan diakui bahwa kitab Daniel ditulis pada sekitar abad ke-2 SZB, dengan asumsi-asumsi yang jauh lebih kuat dan mendukung. Asumsi-asumsi itu didukung dengan bukti literer seperti misalnya penggunaan bentuk bahasa Aram dan bahasa Ibrani yang lebih muda atau dalam perkembangan pemahaman yang lebih kemudian (Mis: kata "Kasdim" yang dulu dipakai untuk menunjuk suatu bangsa di negeri Babel bagian Selatan, dalam kitab Daniel dipakai untuk menunjuk kelompok orang bijaksana tertentu). ${ }^{14}$ Bukti lain yang didapat berdasarkan informasi dalam teks juga menunjukkan lebih tepatnya pandangan ini, yaitu bahwa penulis mengetahui tentang pencemaran Bait Suci oleh Antiokhus IV (7 Desember 167 SZB; lihat Dan. 11:31), tetapi tidak mengetahui tentang kematian Antiokhus IV (musim gugur 164 SZB; lihat Dan. 11:40) dan pemurnian Bait Suci oleh Yudas Makabe pada 14 Desember

\footnotetext{
${ }^{9}$ Lih. Ibid., 3 dan Lacocque, The Book, 13.

${ }^{10}$ Bnd. Singgih, "Dari "Godzilla", 43.

${ }^{11}$ Lih. Collins, Daniel, 27.

${ }^{12}$ Bnd. Ibid, 24.

${ }^{13}$ Siahaan, Tafsiran Alkitab, 51. Mengenai contoh ketidakakuratan pada fakta sejarah lainnya dapat dilihat dalam Collins, Daniel, 29-33.

${ }^{14}$ Siahaan, Tafsiran Alkitab,51; Porteous, Daniel, 13.
} 
164 SZB. ${ }^{15}$ Sehingga dapat ditarik kesimpulan bahwa kitab Daniel ini ditulis pada sekitar abad ke-2 SZB, tetapi tidak lebih dari tahun 164 SZB.

Secara tidak langsung masalah waktu penulisan kitab Daniel ini sebenarnya juga berkaitan dengan masalah kesatuan atau komposisi teks kitab Daniel. ${ }^{16}$ Dikalangan ahli dianggap bahwa komposisi kitab Daniel terjadi secara bertahap. ${ }^{17}$ Berdasarkan pembagian kitab Daniel seperti yang telah dituliskan di atas, dari segi penanggalan dapat dilihat bahwa Daniel A lebih tua atau lebih awal daripada Daniel B dan antara keduanya pada awalnya terpisah satu dengan yang lain. ${ }^{18}$ Tetapi hal ini bukan berarti tidak ada kesatuan teks antara kedua bagian itu. Daniel B dibangun dengan sebagian mendasarkannya atas Daniel A. ${ }^{19}$

\section{Tafsiran Daniel Pasal 9}

Daniel pasal 9 termasuk dalam bagian Daniel B, yang sebagaimana disampaikan di atas merupakan cerita tentang penglihatan-penglihatan atau visi-visi yang dilihat oleh Daniel dan interpretasi/ penjelasan penglihatan-penglihatan itu oleh malaikat kepada Daniel. Tetapi yang menarik dalam Daniel pasal 9 ini adalah perbedaannya dengan pasalpasal lain dalam kitab Daniel. Seow mencatat ada tiga alasan mengapa pasal 9 ini dikatakan berbeda dengan pasal-pasal lain dalam kitab Daniel. Pertama, cerita ini tidak berangkat dari adanya ancaman langsung dari rezim yang menindas (seperti dalam pasal 1, 3 dan 6) dan tidak juga mengenai mimpi ataupun penglihatan oleh tokoh tertentu dalam kitab ini (seperti dalam pasal 2, 4, 5, 7, 8, dan 10-12). ${ }^{20}$ Kedua, cerita ini dimulai dengan refleksi terhadap apa yang ada di dalam "kumpulan kitab", yang mereferensikan kepastian nubuatan dari nabi Yeremia. ${ }^{21}$ Dan ketiga, pasal ini memuat sebuah doa yang panjang yang berisikan pengakuan dan permohonan (ayat 4-19). ${ }^{22}$

Secara umum pasal 9 ini dapat dibagi menjadi dua bagian besar, yaitu ayat 1-20 yang merupakan doa Daniel yang diawali dengan keterangan narator mengenai latar belakang waktu cerita ini dan nubuatan nabi Yeremia yang mendasari doa Daniel; sedangkan ayat 20-27 merupakan penjelasan dari malaikat Gabriel mengenai maksud dari

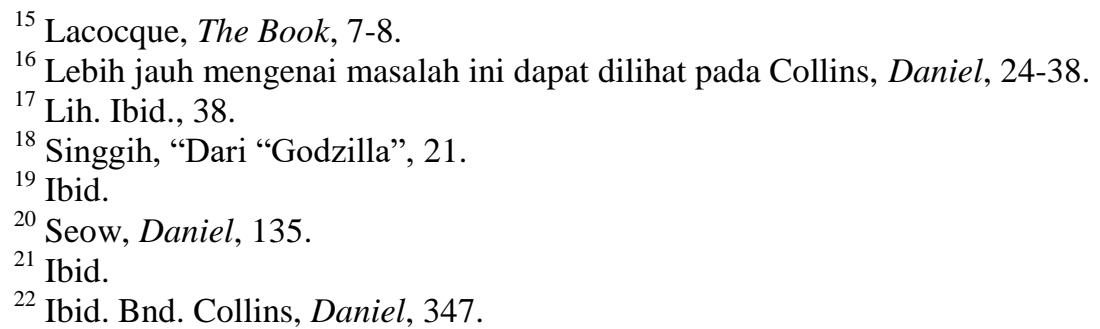


nubuatan nabi Yeremia tentang tujuh puluh tahun. ${ }^{23}$ Tetapi untuk membantu melihat dan memahami struktur dari Daniel pasal 9 ini, dapat dilihat garis besar struktur Daniel pasal 9 yang dibuat oleh John J. Collins berikut ini:

I. 9:1-2 Pendahuluan, keterangan waktu dan alasan (pembacaan nubuatan Yeremia).

II. 9:3-19Doa Daniel:

A. Sebuah keterangan pengantar dalam ayat 3-4a yang menjelaskan bagaimana Daniel mempersiapkan dirinya untuk berdoa.

B. Doa:

1. Pembacaan doa (4b).

2. Pengakuan dosa (5-11a).

3. Pengakuan akan penghukuman ilahi (11b-14).

4. Doa mohon pengampunan (15-19).

III. 9:20-27 Pewahyuan:

A. Pernyataan pengantar (20-21a).

B. Penampakan diri malaikat (21b).

C. Penjelasan dari malaikat (22-27), terdiri dari:

1. Ucapan-ucapan pembukaan (22-23).

2. Nubuatan tentang tujuh puluh kali tujuh tahun (24-27). ${ }^{24}$

Pasal 9 ini dibuka dengan sebuah keterangan waktu yang diberikan oleh penulis, yaitu pada tahun pertama pemerintahan Darius orang Media. Ini artinya era Babilonia telah berakhir dan era Media dimulai. Tentu ada maksud dari penulis kitab Daniel menempatkan cerita dalam pasal ini pada periode waktu seperti itu. Akhir dari periode Babilonia mengindikasikan bahwa nubuatan nabi Yeremia tentang pemulihan akan menemukan realisasinya (Yer. 25:11; 29:10). ${ }^{25}$ Jika dikaitkan dengan apa yang disampaikan pada ayat 2, tentang bagaimana Daniel sedang memperhatikan jumlah tahun pembuangan yang dialami oleh bangsanya berdasarkan nubuatan nabi Yeremia, akan semakin menguatkan maksud penempatan cerita ini dalam periode waktu yang diberikan di ayat 1. Tetapi jika dikaitkan dengan konteks waktu di mana penulis kitab Daniel ini hidup, kita akan mengerti bahwa ini juga dimaksudkan oleh penulis untuk nantinya menjawab pertanyaan, kenapa pada zaman mereka masih ada pendudukan dari bangsa asing dan Bait Suci belum dipulihkan (karena masih dinajiskan); sehingga apakah maksud dari nubuatan 70 tahun yang dimaksud oleh nabi Yeremia. ${ }^{26}$

Pertanyaan tentang bagaimana menginterpretasi 70 tahun menurut nubuat nabi Yeremia adalah sebuah pertanyaan penting bagi penulis kitab Daniel dan komunitasnya pada waktu itu. Doa Daniel dalam pasal 9 ini adalah sebuah upaya untuk menjawab

\footnotetext{
${ }^{23}$ E. Gerrit Singgih, "Daniel 9: Doa di antara penglihatan-penglihatan”, t.p., 2007, 1.

${ }^{24}$ Collins, Daniel, 347.

${ }^{25}$ Lacocque, The Book, 179.

${ }^{26}$ Bnd. Singgih, "Daniel 9, 2.
} 
pertanyaan tersebut, sekaligus mengingatkan mereka apa yang menyebabkan mereka masih mengalami penindasan dari bangsa asing. Doa dalam ayat 4-19 dan juga ayat 20 biasanya dianggap sebagai bagian yang disisipkan kemudian pada bahan asli dalam pasal ini, oleh karena kemiripan bentuk dan isinya dengan doa-doa tradisional. ${ }^{27}$ Tetapi besar kemungkinan sisipan ini dilakukan sendiri oleh penyusun kitab Daniel. ${ }^{28}$

Doa Daniel ini berisikan tentang pengakuan dosa, pengakuan akan penghukuman ilahi dan permohonan pengampunan (lihat struktur yang dibuat Collins di atas). Daniel mengakui dosanya dan juga dosa bangsanya, serta mengakui kalau pembuangan yang mereka alami itu sebagai akibat dari kesalahan-kesalahan mereka. Daniel kemudian memohon pengampunan dan pemulihan atas Israel dan Yerusalem dari Tuhan. Dengan melihat isi doa Daniel ini, akan kelihatan corak atau perspektif dari teologi deuteronomis, di mana dalam perspektif deuteronomistik penghukuman yang dialami oleh bangsa Israel (kehancuran Yerusalem dan Bait Suci) dipahami terjadi oleh karena dosa-dosa mereka sendiri dan oleh sebab itu mereka harus bertobat dan berbalik kepada Allah. ${ }^{29}$

Tetapi menurut Collins teologi yang terkandung dalam Daniel pasal 9 ini sebenarnya sangat berbeda dengan teologi Deuteronomis dalam doa. ${ }^{30}$ Apa yang disampaikan oleh malaikat kemudian sama sekali tidak mengindikasikan sebagai respons terhadap doa Daniel. ${ }^{31}$ Firman itu keluar pada awal permohonan Daniel dan saat akhir itu akan datang pada waktu yang telah ditetapkan karena sudah diputuskan, bukan karena pertobatan dari umat. ${ }^{32}$ Memang dengan melihat pasal 9 secara keseluruhan tidak ada kaitan yang secara jelas dengan teologi deuteronomis selain yang terkandung dalam doa. Jika demikian, apa sebenarnya maksud penulis kitab Daniel memasukkan doa Daniel ini ke dalam pasal 9 dan apa maknanya?

Yang perlu diingat adalah bahwa doa Daniel ini memang mirip dengan bentuk doa tradisional dan doa ini bercorak liturgis dengan melihat persiapan yang Daniel lakukan seperti berpuasa, mengenakan kain kabung dan abu. ${ }^{33}$ Dan yang juga perlu diingat adalah bahwa pasal 9 ini adalah sebuah usaha untuk menjawab pertanyaan mengapa penindasan dan penganiayaan terhadap orang Israel pada abad ke-2 SZB (konteks waktu penulisan kitab Daniel) masih terus terjadi padahal zaman Babilonia sudah berakhir. Dalam doa kita

\footnotetext{
${ }^{27}$ Siahaan, Tafsiran Alkitab, 162; Seow, Daniel, 141.

${ }^{28}$ Siahaan, Tafsiran Alkitab, 163.

${ }^{29}$ Collins, Daniel, 359; Seow, Daniel, 143-144.

${ }^{30}$ Lih. Collins, Daniel, 360.

${ }^{31}$ Ibid.

32 Ibid.

${ }^{33}$ Lih. Lacocque, The Book, 180-182.
} 
melihat dengan jelas bahwa penekanannya terletak pada pengakuan dosa yang dibuat oleh Daniel. Tetapi kita harus bertanya pula, dalam konteks penulis kitab Daniel, dosa apakah yang masih menyebabkan mereka mengalami penindasan dan penganiayaan yang seringkali dipahami sebagai penghukuman dari Tuhan. Dalam penjelasan Collins, berdasarkan teks-teks lain dalam periode hellenis tentang penganiayaan sebagai penghukuman atas dosa (misalnya dalam 2 Makabe 7:18), tekanannya sebenarnya adalah pada dosa si "penajis" dari bangsa asing (dalam konteks penulis kitab Daniel tentulah ini Antiokhus IV Epifanes). ${ }^{34}$

Artinya bahwa kenajisan yang dibuat oleh Antiokhus IV Epifanes terhadap Bait Suci telah menyebabkan hilangnya kekudusan dan kehilangan kekudusan itu berarti berada dalam keadaaan berdosa. ${ }^{35}$ Dan secara tidak langsung, ketika Bait Suci dinajiskan, itu artinya orang Israel ikut ketularan kenajisan itu sehingga mereka berdosa. ${ }^{36}$ Sehingga dengan demikian dosa di sini tidak dimengerti atau dipahami secara etis-moral (sebagaimana yang biasanya muncul dalam perspektif deuteronomis), tetapi secara ritual (kultis), di mana dipahami bahwa dosa adalah ketidakkudusan karena sumber kekudusan tidak ada lagi di dalam kehidupan sehari-hari. ${ }^{37}$ Ini mungkin yang dapat menjawab mengapa doa Daniel dimasukkan dalam pasal 9 ini oleh penulis kitab Daniel.

Doa Daniel dalam pasal 9 ini adalah sesuatu yang penting dan bukan sekedar ditambahkan oleh penulis kitab Daniel. Norman Porteous mengatakan, "tanpa adanya doa ini, sesuatu yang penting hilang dalam kitab Daniel". ${ }^{38}$ Doa ini menunjukkan tindakantindakan Allah pada masa lampau, seperti peristiwa keluaran dari Mesir (ayat 15), perjanjian Allah dengan umat-Nya (ayat 4), pengutusan para nabi (ayat 6 dan 10); dan doa ini juga memberikan gambaran yang sangat jelas dari bagaimana ungkapan iman Israel mendapatkan belas kasihan Allah. ${ }^{39}$ Jadi dari sini jelas bahwa permohonan ampun yang Daniel sampaikan dalam doanya, bukan didasarkan pada usaha mereka untuk mendapatkan pengampunan itu (seperti misalnya berpuasa, berkabung), tetapi kepada belas kasihan Allah (ayat 18-19). Bila ini dikaitkan dengan konsep dosa ritual/ kultis di atas, maka menurut penulis kitab Daniel, hanya Allah yang sanggup melepaskan mereka dari dosa itu dengan cara menghancurkan "si penajis" dan memulihkan Yerusalem serta

\footnotetext{
${ }^{34}$ Collins, Daniel, 360.

${ }^{35}$ Singgih, "Daniel 9, 2-3.

${ }^{36}$ Ibid, 3 .

37 Ibid.

${ }^{38}$ Porteous, Daniel, 136.

${ }^{39}$ Ibid. Lih. juga Siahaan, Tafsiran Alkitab, 169.
} 
Bait Suci. Ini merupakan ungkapan permohonan mereka yang mengalami penindasan dan diungkapkan dalam doa Daniel tersebut.

Masuk ke bagian selanjutnya, Daniel kemudian dijumpai oleh malaikat Gabriel yang membawa firman tentang penjelasan makna ungkapan 70 tahun dalam nubuat nabi Yeremia. Malaikat Gabriel datang kepada Daniel untuk memberikan pengertian kepada Daniel tentang makna 70 tahun dari nubuat Yeremia karena Daniel adalah orang yang dikasihi (ayat 22-23). Gabriel memberikan penjelasan bahwa 70 tahun itu adalah berarti 70 kali 7 minggu. Tetapi kata minggu di sini tidak boleh kita artikan secara harafiah, karena kata Ibrani untuk "minggu" dapat berarti periode tujuh (hari, bulan atau tahun) dan karena Yeremia berbicara tentang 70 tahun, tafsiran yang biasa adalah 70 "minggu" dalam tahun-tahun atau 490 tahun (70 kali 7 tahun). ${ }^{40}$ Dalam kitab Imamat dibicarakan tentang tahun Yobel sebagai tahun pembebasan, yaitu tujuh "minggu" tahun atau tujuh kali tujuh tahun atau empat puluh sembilan tahun (Im. 25:8). ${ }^{41}$ Daniel pasal 9 ini menafsirkan kembali nubuat nabi Yeremia menurut pemahaman Imamat 26:18, yaitu bahwa jika umat terus berbuat dosa, maka Allah akan menghukum mereka tujuh kali lipat, yang berarti dalam kaitan dengan nubuat Yeremia tujuh kali tujuh puluh tahun atau sepuluh kali tahun Yobel (490 tahun). ${ }^{42}$ Dosa dalam konteks pemahaman kita dalam Daniel pasal 9 ini harus diingat seperti yang dituliskan di atas, bukanlah dosa yang dipahami secara etis-moral tetapi secara ritual/ kultis. Dengan demikian orang Israel baru akan mengalami pemulihan jika sumber ketidakkudusan yang menyebabkan mereka juga tidak kudus sehingga berdosa, telah dihukum atau dimusnahkan dan Bait Suci sebagai pusat kultis telah dipulihkan.

Dari apa yang disampaikan oleh malaikat Gabriel dalam ayat 24, selama periode 70 tahun tersebut akan terjadi beberapa hal, yaitu: pertama, kefasikan akan diakhiri atau dilenyapkan; kedua, dosa akan diakhiri; ketiga, kesalahan akan dihapuskan; keempat, keadilan yang kekal akan diwujudkan; kelima, penglihatan dan nabi akan tergenapkan; dan keenam atau puncaknya, tempat yang kudus akan dipulihkan. ${ }^{43}$ Berdasarkan penjelasan dalam ayat 25-27, kita juga melihat pembagian periode 70 tahun itu ke dalam tiga bagian waktu, yaitu: pertama, sampai pada kedatangan seorang yang diurapi ada tujuh kali tujuh masa; kedua, ada enam puluh dua kali tujuh masa lamanya kota itu akan dibangun kembali dengan tanah lapang dan paritnya (yang dimaksud kemungkinan besar

\footnotetext{
${ }^{40}$ Seow, Daniel, 146.

${ }^{41}$ Ibid.

${ }^{42}$ Ibid, 146-147.

${ }^{43}$ Ibid, 147.
} 
adalah kota Yerusalem) dan setelah enam puluh dua kali tujuh masa itu akan disingkirkan yang diurapi itu; ketiga, ada satu kali tujuh masa di mana raja itu (Antiokhus Epifanes) akan membuat suatu perjanjian yang berat, dan di tengah-tengah tujuh masa itu ia akan menghentikan korban sembelihan dan korban santapan. ${ }^{44}$

Siapakah yang dimaksud dengan seorang yang diurapi dalam pembagian waktu yang pertama dari periode 70 tahun? Ada beberapa pendapat yang dikemukakan oleh para ahli. Beberapa ahli menafsirkannya sebagai Koresh yang dalam Yesaya 45:1 disebut sebagai yang "diurapi". ${ }^{45}$ Ahli yang lain mengganggap yang diurapi itu adalah imam besar Yosua, yang mendapat kedudukannya setelah satu periode tahun Yobel (49 tahun) yang dihitung mulai dari awal masa pembuangan pada tahun 586 SZB. ${ }^{46}$ Pendapat yang lain menafsirkan kalau itu adalah Zerubabel yang adalah keturunan Daud, berdasarkan Ezra 3:2 dan dalam kitab Hagai dan Zakharia. ${ }^{47}$ Memang kesulitannya adalah bagaimana menginterpretasi yang dimaksud "yang diurapi”, karena itu dapat dikenakan kepada seorang raja (1Sam. 2:10, 35; 9:16; 10:1) ataupun seorang imam (Im. 4:3; 2 Makabe 1:10; Neh. 11:11; Yer. 20:1). ${ }^{48}$ Tetapi yang lebih mungkin adalah imam besar Yosua, jika kita mendasarkan pada tafsiran bahwa yang dimaksud yang diurapi kedua pada ayat 26 adalah imam besar Onias III.

Inti dari pemberitaan yang dibawa oleh malaikat Gabriel adalah bahwa saat pemulihan $^{49}$ itu akan tiba bagi umat Israel setelah "si penajis", yaitu Antiokhus IV Epifanes dihukum dan dibinasakan (ayat 27). Dan Allah tidak hanya akan menghancurkan Antiokhus, tetapi juga Baal Shamem, ilah yang disembah oleh Antiokhus (2 Makabe 6:2) sebagai pembalasan-Nya atas apa yang telah dialami oleh umat. ${ }^{50}$ Dengan demikian jelas bahwa tujuan penulis kitab Daniel dalam pasal 9 ini adalah untuk menguatkan umat di tengah-tengah penindasan yang dialami dan kebingungan akan penafsiran dari yang dimaksud 70 tahun dalam nubuat nabi Yeremia. Penulis kitab Daniel mereinterpretasi nubuat Yeremia sehingga cocok untuk zamannya. ${ }^{51}$

${ }^{44}$ Bnd. Lacocque, The Book, 194. Lih. juga Seow, Daniel, 148.

${ }^{45}$ Seow, Daniel, 148.

${ }^{46}$ Ibid.

${ }^{47}$ Porteous, Daniel, 142

${ }^{48}$ Seow, Daniel, 148.

${ }^{49}$ Puncaknya mungkin adalah pada saat Bait Suci dimurnikan kembali pada tahun 164 SZB oleh Yudas Makabeus (walaupun penulis kitab Daniel tidak sampai melihat peristiwa ini dan tidak ada rujukan dalam kitabnya mengenai hal ini). Lih. Singgih, "Daniel 9", 4.

${ }^{50}$ Seow, Daniel, 151.

${ }^{51}$ Singgih, "Daniel 9", 4. 


\section{Kesimpulan}

Sebagai bangsa yang pernah mengalami penindasan dan penjajahan, seharusnya kita tidak terlalu sulit untuk mengerti dan memahami situasi yang dialami oleh umat Israel pada sekitar abad ke-2 SZB. Usaha yang dilakukan oleh penulis kitab Daniel lewat tulisannya, secara khusus pasal 9 ini adalah sebuah usaha untuk tetap memberikan harapan kepada tindakan Allah dalam situasi sulit yang mereka hadapi saat itu. Lalu kemudian, apa sebenarnya sumbangsih dari pasal 9 dari kitab Daniel ini bagi konteks kita pada masa kini. Kita memang sudah tidak mengalami lagi zaman penjajahan seperti dulu, tetapi mentalitas dan pengaruh-pengaruh dari masa penjajahan atau masa kolonial itu masih dapat kita lihat dan jumpai dalam kehidupan kita saat ini. Kalau kita menghubungkan dengan konteks doa Daniel di atas yang bercorak pengakuan dosa secara kultis/ ritual, karena mereka tidak dapat melaksanakan kehidupan peribadahan mereka dengan baik dan adanya pengaruh dari bangsa yang menindas mereka dalam proses itu; kita mungkin dapat bertanya, apakah ada pengaruh dari kaum penjajah terhadap kehidupan peribadahan kita saat ini yang mungkin tidak sesuai sebenarnya dengan konteks dan budaya kita. Pertanyaan ini mungkin terlalu jauh, tetapi tetap menarik untuk melihatnya ketika kita merefleksikan apa yang dialami oleh umat dalam konteks penulisan kitab Daniel.

Memang dibutuhkan penelitian yang mendalam untuk melihat sejauh mana dan seberapa besar pengaruh peninggalan masa-masa kolonial dalam kehidupan kultis di gereja-gereja Indonesia masa kini. Tetapi di sini kita akan melihat secara fenomenologis saja pengaruh-pengaruh yang muncul tersebut. Salah satu yang dapat diangkat adalah sikap inferior kita ketika berhadapan dengan orang asing, sebagai pengaruh dari masa kolonial yang kuat terlihat pada bangsa kita. Penulis menyoroti hal ini secara khusus dan lebih sempit dalam konteks gereja adalah dikalangan Pentakosta-Karismatik. Ketika dalam sebuah kegiatan peribadahan (sebut saja KKR) yang menjadi pembicara adalah pengkhotbah dari luar negeri, maka orang akan berduyun-duyun datang dan menghadirinya. Bahkan tidak peduli kalau tempat tinggal mereka kadang sangat jauh dari tempat pelaksanaan acara itu (ada yang dari kota-kota yang jaraknya cukup jauh). Seperti yang terjadi beberapa tahun lalu di Jakarta, ketika seorang pengkhotbah terkenal dari luar negeri datang dan mengadakan KKR, orang-orang dari berbagai kota datang ke Jakarta untuk mengikuti. Dan karena sikap inferior ini, kadang tidak dikritisi lagi apa-apa yang disampaikan oleh pengkhotbah dari luar negeri itu, apakah sesuai dengan konteks kita di Indonesia dan bahkan apakah memang digali secara bertanggungjawab dari Alkitab. 
Bahkan orang tidak pernah memikirkan bilakah ada sebenarnya motivasi-motivasi tertentu dalam memanfaatkan acara-acara KKR seperti itu untuk kepentingan pribadi si pengkhotbah.

Cenderung untuk menerima begitu saja dan tidak memikirkan lagi secara kritis apa yang disampaikan dalam khotbah adalah mentalitas yang muncul sebagai peninggalan masa kolonial. Karena tentu pada masa penjajahan atau kolonialisme dulu tidak ada orang yang dijajah berani mempertanyakan apa yang diperbuat oleh penjajahnya. Kalaupun ada yang bertanya, pasti langsung diancam atau dihukum karena berani mempertanyakan tindakan kaum penjajah. Bertanya dianggap sebagai sebuah usaha untuk melawan dan membangkang terhadap apa yang diperbuat oleh kaum penjajah. Dengan demikian terciptalah mentalitas yang dapat kita lihat pada kebanyakan orang Indonesia saat ini. Segala sesuatu diterima begitu saja. Sehingga banyak pengajaran-pengajaran yang mungkin tidak sesuai dengan penafsiran kitab Suci yang kontekstual, berkembang di tengah-tengah jemaat.

Saat ini mungkin kita tidak lagi mengalami bentuk-bentuk penjajahan seperti yang terjadi dulu pada masa kolonial. Tetapi kalau kita lihat, sebenarnya banyak muncul bentuk penjajahan baru yang juga dapat mengancam secara tidak langsung kehidupan peribadahan kita. Dan ini mungkin mirip dengan situasi yang dialami oleh para pembaca awal kitab Daniel. Salah satu contoh bentuk penjajahan dan penindasan baru adalah industrialisasi. Banyak pabrik yang tersebar di negara kita adalah merupakan kepunyaan orang asing. Walaupun telah ada aturan atau undang-undang yang mengatur tentang masalah industri dan tenaga kerjanya, seperti UU No. 13 tahun 2001 tentang tenaga kerja, masih banyak terjadi penyimpangan dan ketidaksesuaian dengan pelaksanaannya di lapangan. Seperti yang misalnya penulis lihat dan dengar sendiri dari apa yang terjadi pada beberapa jemaat di gereja tempat penulis melayani, yang bekerja pada salah satu pabrik yang dimiliki oleh orang asing. Seringkali pada hari minggu (waktu untuk beribadah) pun mereka tetap harus masuk kerja dengan alasan dari pihak pabrik adalah "kejar target" dan ini menyebabkan mereka tidak dapat beribadah di gereja. Seringkali pula ketika mereka lembur tidak mendapatkan upah sebagaimana mestinya dalam aturan lembur itu sendiri.

Bentuk penindasan seperti ini yang secara tidak langsung berkaitan dengan kehidupan peribadahan, mungkin relevan dengan bagaimana mengaplikasikan makna Daniel pasal 9 dalam konteks masa kini. Tantangannya adalah bagaimana membina iman umat yang mengalami situasi berat ketika mereka mereka bekerja di pabrik. Atau 
bagaimana mereka harus melangsungkan kehidupan peribadahan mereka dalam situasi seperti itu. Memang kita tidak dapat menjanjikan bahwa keadaan mereka akan segera berubah ke arah yang lebih baik sebagaimana harapan yang diberikan oleh penulis kitab Daniel kepada orang-orang sezamannya pada waktu itu. Tetapi yang dapat dilakukan adalah mengajak mereka menghayati kehadiran Allah bahkan dalam situasi-situasi yang berat sekalipun, yang mereka alami. Tetapi ini bukan berarti bahwa kita membiarkan penindasan itu juga terus terjadi. Menghayati kehadiran Allah dapat diwujudkan dalam perlawanan kepada segala bentuk penindasan yang terjadi pada masa kini.

\section{Kepustakaan}

Collins, John J. Daniel, Hermeneia Series. Minneapolis: Fortress Press, 1993.

E. Gerrit Singgih. "Dari "Godzilla" Ke "Bandot": Fungsi Penglihatan Mengenai Binatangbinatang Di Daniel 7-8 Dalam Bagian Kedua Kitab Daniel”, dalam Marsunu, Y. M. Setyo (ed.), Apokaliptik. Jakarta: LBI, 2007.

E. Gerrit Singgih. “Daniel 9: Doa di antara penglihatan-penglihatan”, t.p., 2007.

Lacocque, Andre. The Book of Daniel. London: SPCK, 1979.

Porteous, Norman W. Daniel, The Old Testament Library. London: SCM Press, 1965.

Seow, C. L. Daniel. Louisville: Westminster Bible Companion, Westminster John Knox Press, 2003.

Siahaan, S. M. \& Paterson, Robert M. Tafsiran Alkitab: Kitab Daniel: Latar Belakang, Tafsiran dan Pesan. Jakarta: BPK Gunung Mulia, 1994.

Sugirtharajah, R. S. Postcolonial Criticism and Biblical Interpretation. Oxford: Oxford Universiy Press, 2002.

. The Bible and Empire: Postcolonial Explorations. Cambridge: Cambridge University Press, 2005. 